\title{
Five new species of the genus Carpelimus Leach, 1819, from the Oriental region (Coleoptera: Staphylinidae: Oxytelinae)
}

\section{Пять новых видов рода Carpelimus Leach, 1819 из Восточной области (Coleoptera: Staphylinidae: Oxytelinae)}

\author{
M.Yu. Gildenkov \\ М.Ю. Гильденков
}

Smolensk State University, Przhevalsky str. 4, Smolensk 214000, Russia. E-mail: mgildenkov@mail.ru
Смоленский государственный университет, Пржевальского 4, Смоленск 214000, Россия.

KEY WORDS: Coleoptera, Staphylinidae, Carpelimus, new species, Oriental region, China, Northern India, Nepal, Thailand.

КЛЮЧЕВЫЕ СЛОВА: Coleoptera, Staphylinidae, Carpelimus, новый вид, Восточная биогеографическая область, Китай, Северная Индия, Непал, Таиланд.

ABSTRACT: Five new species of the genus Carpelimus are described from the Oriental biogeographic region: Carpelimus (Trogophloeus) asperus, sp.n. from from North India, Carpelimus (Trogophloeus) geminus, sp.n. from Nepal, Carpelimus (Trogophloeus) guillaumei, sp.n. from South China and Thailand, and Carpelimus (Bucephalinus) rubrus, sp.n. from North India and Nepal.

РЕЗЮМЕ: Описываются пять новых видов рода Carpelimus из Восточной биогеографической области: Carpelimus (Trogophloeus) asperus, sp.n. из Южного Китая, Carpelimus (Trogophloeus) fuligus, sp.n. из Северной Индии, Carpelimus (Trogophloeus) geminus, sp.n. из Непала, Carpelimus (Trogophloeus) guillaumei, sp.n. из Южного Китая и Таиланда, Carpelimus (Bucephalinus) rubrus, sp.n. из Северной Индии и Непала.

\section{Introduction}

The members of the genus Carpelimus Leach, 1819 are abundant on the shores of various water bodies. The Carpelimus fauna of the Palaearctic and tropical Africa has now been generally well-studied [Gildenkov, 2001a, b; 2002; 2003a, b; 2007a, b; 2011a, b; 2012; 2013a, b, d; 2015 b; 2016a, b; 2017]. In contrast, the fauna of the Oriental biogeographic region remains largely unexplored, although much work has already been done [Gildenkov, 2013c, d, e; 2014a, b, c, d; 2015a, b; 2016b]. For instance, one of the taxonomically most challenging is the «taprobanae» species group, whose South China, Carpelimus (Trogophloeus) fuligus, sp.n.

members can often be clearly distinguished only by the morphology of the aedeagus.

This paper is based on the specimens deposited in the following collections: BNHM - Natural History Museum (London, Great Britain); cGR - private collection of Guillaume de Rougemont (Oxford, Great Britain); cMG - private collection of M. Gildenkov (Smolensk, Russia); cMSch - private collection of Michael Schülke (Berlin, Germany); FMNH — Field Museum of Natural History (Chicago, USA); NHMW Naturhistorisches Museum Wien (Austria); NKME Naturkundemuseum Erfurt (Germany); ZFMK — Zoologisches Forschungsinstitut und Museum Alexander Koenig (Bonn, Germany).

In the present study, standard methods were used for the taxonomic research of insects; the preparations were made on an MBS-10 binocular microscope. The genital preparations were processed using $10 \% \mathrm{KOH}$ and then fixed in euparal. In the descriptions and diagnoses, the following standard units were used for the length-towidth ratio of the head, pronotum, and elytra: 7 standard units $=0.1 \mathrm{~mm}$; thus, 1 standard unit is about 0.0143 $\mathrm{mm}$. Photographs were taken with a Canon EOS 5D Mark III camera and a Canon MP-E $65 \mathrm{~mm}$ objective using the extended focus technology.

\section{Carpelimus (Trogophloeus) asperus Gildenkov, sp.n. Figs. 1, 5-7.}

MATERIAL. Holotype, OT' "HONG KONG, KARC VI.1996 | G. de Rougemont" "Flight interception trap" "Holotypus Carpelimus asperus | det. M. Gildenkov, 2018" (cGR). Paratypes: $10^{7}$ "Hong Kong K.A.R.C. VIII.91 G. Ades" "Malaise trap" "Rougemont collection" "Paratypus Carpelimus asperus | det. M. Gildenkov, 2018" (cMG); $10^{7}$ "HONG KONG CUHK III.1996 | G. de Rougemont" "Flight interception trap" "Paratypus Carpelimus asperus | det. M.

How to cite this article: Gildenkov M.Yu. 2018. Five new species of the genus Carpelimus Leach, 1819, from the Oriental region (Coleoptera: Staphylinidae: Oxytelinae) // Russian Entomol. J. Vol.27. No.2. P.135-142. doi: 10.15298/rusentj.27.2.03 
Gildenkov, 2018" (cGR); 1ㅇ, 1 ex. "HONG KONG Tai Po VII.1996 | G. de Rougemont" "Flight interception trap" "Paratypus Carpelimus asperus | det. M. Gildenkov, 2018" (cGR; 1 ex. - cMG); 1 ex. "HONG KONG Tai Po V.1996 | G. de Rougemont" "Flight interception trap" "Paratypus Carpelimus asperus | det. M. Gildenkov, 2018" (cGR).

DESCRIPTION (holotype). Length $2.0 \mathrm{~mm}$. Colouration brown. Head and pronotum dark brown, abdomen blackbrown, elytra reddish brown; legs and antennae yellowish brown, antennal segments 1 and 9-11 much paler than others. Integument slightly shining, body with short light-coloured hairs.

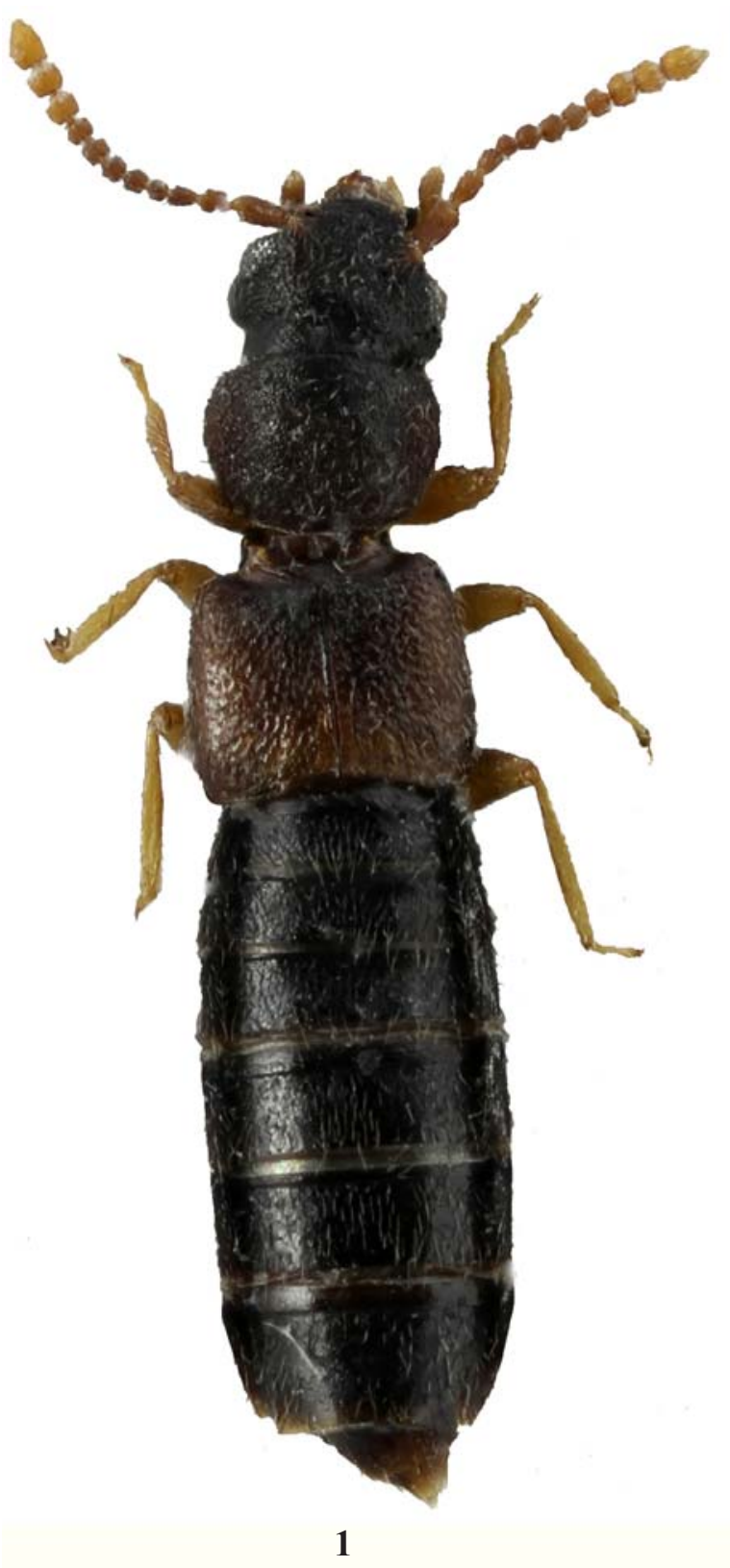

Head transverse, with wide base, ratio of head length (from neck mid-length to anterior margin of clypeus) to its maximum width about 20:26. Neck constriction prominent. Eyes small, slightly convex. Temples well-developed, round, eye diameter in dorsal view slightly smaller than temple length. Head widest across temples (Fig. 1). Head surface densely shagreened. Antennae short, antennal segments 1-3 elongate; segments 4-6 slightly transverse; segments 7-10 transverse; segment 11 elongate, conical. Last 3 segments more massive than others and form loose club (Fig. 1).

Pronotum widest about $2 / 3$ its length from base, then narrowed. Lateral margin with small notch near base (Fig. 1).

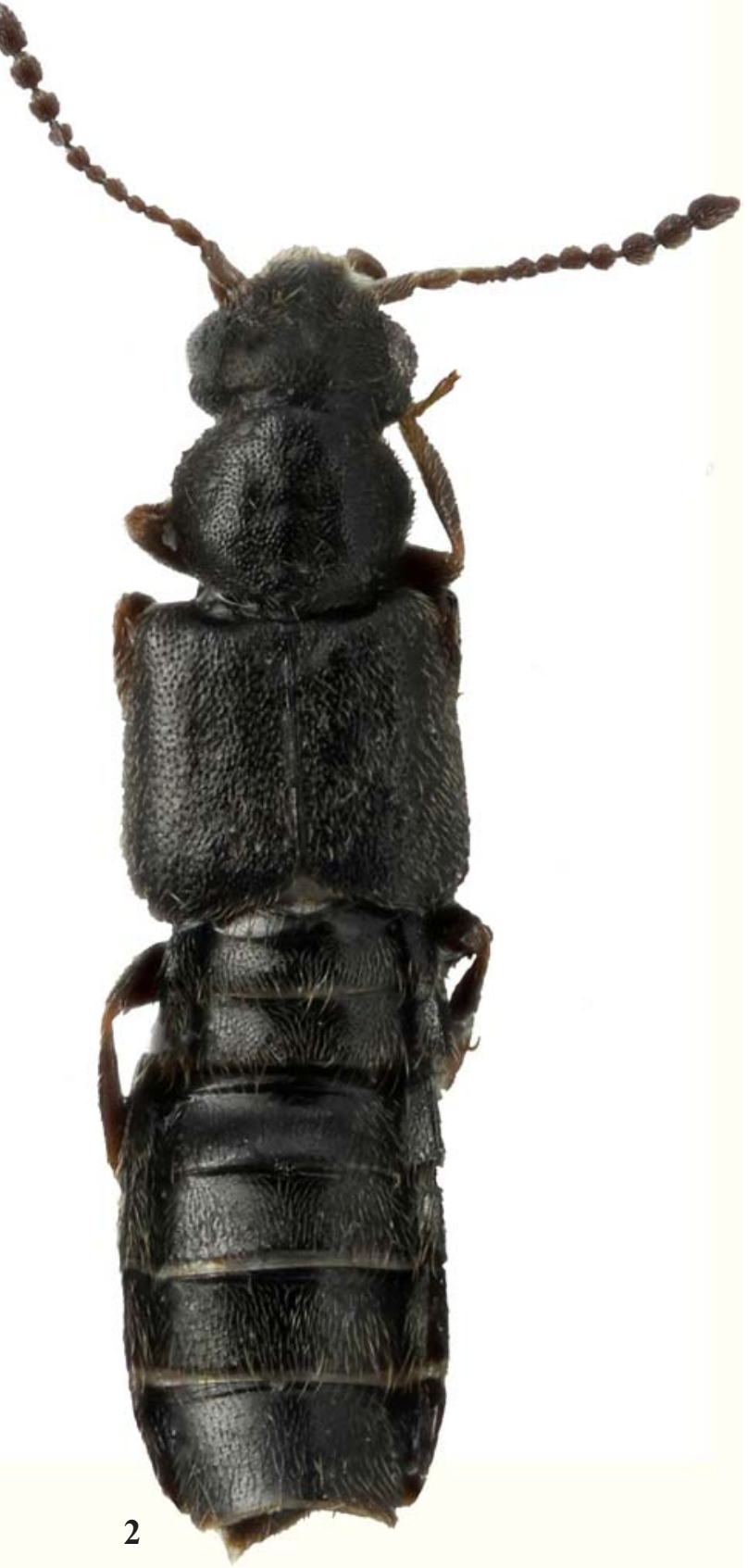

Figs 1-2. Carpelimus spp., holotypes, males, dorsal view: 1 - Carpelimus (Trogophloeus) asperus, sp.n.; 2 - Carpelimus (Trogophloeus) fuligus, sp.n.

Рис. 1-2. Carpelimus spр., глотипы, самцы, сверху: 1 -Carpelimus (Trogophloeus) asperus, sp.n.; 2 - Carpelimus (Trogophloeus) fuligus, sp.n. 
Ratio of pronotum length to its maximum width about 20:30. Surface of pronotum densely shagreened, similarly to head surface. Base of pronotal disc with shallow, symmetrical, round depressions. Central part of disc with almost indistinct symmetrical, round depressions (Fig. 1).

Ratio of length of elytra to their combined width about 31:36. Scutellum with shallow round depressions (Fig. 1). Elytra with rather distinct, fine and dense punctation. Diameter of punctures about equal to that of eye facet. Distances between punctures significantly smaller than puncture diameter, interspaces often smoothly shagreened.

Abdomen delicately shagreened.

Aedeagus of characteristic structure (Figs 5-6).

Female. Sexual dimorphism absent, female morphologically similar to male. Spermatheca of characteristic structure (Fig. 7).

COMPARATIVE REMARKS. The new species belongs to the "taprobanae" species group. In this group, the new species is most similar in size and densely shagreened surface of the head and pronotum to a closely related species, Carpelimus (Trogophloeus) flavomustachus Gildenkov, 2013. The new species differs markedly by its shorter elytra and can be clearly distinguished by the structure of the aedeagus [Gildenkov, 2015b, p. 384, figs. 18: 12-13]. It can be easily differentiated from most species of the group by the lack of punctation on the head and pronotum.

DISTRIBUTION. South China.

ETYMOLOGY. From Latin asper (rough) referring to the densely shagreened surface of the head and pronotum.

Carpelimus (Trogophloeus) fuligus Gildenkov, sp.n. Figs 2, 8-10.

MATERIAL. Holotype, $\sigma^{7}$ "NE INDIA, ARUNACHAL PR. 8 $\mathrm{km}$ S Jamiri - SESSA vicinity $27^{\circ} 07^{\prime}-09^{\prime} \mathrm{N} 92^{\circ} 34^{\prime} \mathrm{E}, 350 \mathrm{~m} \mathrm{~L}$. Dembick leg., 26.v.-4.vi.2005, BMNH 2006 - 48” (BNHM) Paratypes: $30^{7} \sigma^{7}, 7 \circ 0,18$ ex. "NE INDIA, ARUNACHAL PR. 8 km S Jamiri - SESSA vicinity $27^{\circ} 07^{\prime}-09^{\prime} \mathrm{N} 92^{\circ} 34^{\prime} \mathrm{E}$, 350m L. Dembick leg., 26.v.-4.vi.2005, BMNH 2006 - 48" (BNHM; 10', 1 , 3 ex. - cMG).

DESCRIPTION (holotype). Length $2.0 \mathrm{~mm}$. Colouration black, legs and antennae black-brown. Integument slightly shining, body with short light-coloured hairs.

Head transverse, with wide base, ratio of head length (from neck mid-length to anterior margin of clypeus) to its maximum width about 20:27. Neck constriction prominent. Eyes rather large, convex. Temples well-developed, round, eye diameter in dorsal view about twice as long as temple length. Head widest across eyes (Fig. 2). Head surface with delicate, fine and dense punctation. Diameter of punctures about 3 times as small as eye facet. Distances between punctures slightly smaller than their diameter, interspaces smooth, slightly shining. Antennae rather long, antennal segments $1-7$ elongate; segments $8-10$ about as long as wide; segment 11 elongate, conical. Last 3 segments more massive than others and form loose club (Fig. 2).

Pronotum widest about $2 / 3$ its length from base, then narrowed. Lateral margin smoothly rounded (Fig. 2). Ratio of pronotum length to its maximum width about 23:28. Surface of pronotum with delicate, distinct, fine, and dense punctation, distances between punctures slightly smaller than their diameter, interspaces smooth, slightly shining. Punctation similar to that on head. Base of pronotal disc with prominent, symmetrical, widely crescent-shaped depressions. Central part of disc with rather deep, oval depressions merging across midline to single butterfly-shaped depression (Fig. 2).

Ratio of length of elytra to their combined width about
36:40. Scutellum with shallow rounded depressions (Fig. 2). Elytra with delicate, fine and dense punctation. Diameter of punctures about 1.5 times as small as eye facet. Distances between punctures slightly smaller than their diameter, interspaces smooth, slightly shining.

Abdomen delicately shagreened.

Aedeagus of characteristic structure (Figs 8-9).

Female. Sexual dimorphism absent, female morphologically similar to male. Spermatheca of characteristic structure (Fig. 10).

COMPARATIVE REMARKS. The new species is somewhat similar to Carpelimus guillaumei sp.n., which is described below. It differs in a darker colouration, somewhat more developed eyes, and longer antennae. It can be clearly distinguished by the structure of the aedeagus (Figs 8-9, 1415).

DISTRIBUTION. North India.

ETYMOLOGY. From Latin fuligo (soot) referring to the black colouration of the beetle.

\section{Carpelimus (Trogophloeus) geminus Gildenkov, sp.n.}

Figs 3, 11-13.

MATERIAL. Holotype, $\sigma^{7}$ "NEPAL, Maewa Khola Sanghu Lower oak forest $27^{\circ} 20^{\prime} \mathrm{N} ; 87^{\circ} 32^{\prime} \mathrm{E} 16 / 10 / 1961^{\prime}$ " On mosses and liverworts on damp shaded sandy bank no humus" "K.H. Hyatt, 1961-62 BMNH Nepal Exped BMNH \{E\} 1975-287" (BNHM). Paratypes: $10^{7}$ "NEPAL: Topke Gold $27^{\circ} 38^{\prime}$ N, $87^{\circ} 35^{\prime}$ e. 28.X.1961. 6.12 .500 ft." "Funnel sample no. 274" "BMNH Nepal Exp. 19611962 B.M. 1975-287” (cMG); $10^{\top}, 19$ “NEPAL, Maewa Khola Sanghu Lower oak forest $27^{\circ} 20^{\prime} \mathrm{N} ; 87^{\circ} 32^{\prime} \mathrm{E} 16 / 10 / 1961$ " "On mosses and liverworts on damp shaded sandy bank no humus" "K.H. Hyatt, 1961-62 BMNH Nepal Exped BMNH \{E\} 1975-287" (BNHM); $2 \sigma^{\top} \sigma^{7}, 2$ ㅇ "NEP: Tumlingtar Dist., Arun Valley, 3 mi E Tumlingtar Airstrip 1200', 19-III-1975" "FMHD $\sigma^{7} 75-38$, sphagnum moss in dry sal for., M.Marks" (FMNH; $1 \sigma^{\top}, 1$ ㅇ- - cMG).

DESCRIPTION (holotype). Length $1.8 \mathrm{~mm}$. Colouration brown, legs and antennae yellowish brown, antennal segments 1 and 9-11 slightly paler than others. Integument slightly shining, body with short light hairs.

Head transverse, with wide base, ratio of head length (from neck mid-length to anterior margin of clypeus) to its maximum width about 18:24. Neck constriction prominent. Eyes rather large, slightly convex. Temples well-developed, round, eye diameter in dorsal view only slightly longer than temple length. Head widest across temples (Fig. 3). Head surface with rather distinct, fine and dense punctation. Diameter of punctures about twice as small as that of eye facet. Distances between punctures much smaller than their diameter, interspaces smooth, slightly shining. Antennae rather short, antennal segments 1-5 elongate; segments 6-7 about as wide as long; segments 8-10 slightly transverse; segment 11 elongate, conical. Last 3 segments more massive than others and form loose club (Fig. 3).

Pronotum widest about $2 / 3$ its length from base, then narrowed. Lateral margin smoothly rounded (Fig. 3). Ratio of pronotum length to its maximum width about 19:26. Surface of pronotum with rather distinct, fine and dense punctation. Diameter of punctures about twice as small as eye facet. Distances between punctures much smaller than their diameter, interspaces smooth, slightly shining. Punctation similar to that on head. Base of pronotal disc with almost indistinct, symmetrical, round depressions (Fig. 3).

Ratio of length of elytra to their combined width about 25:32. Elytra with shallow longitudinal depressions extending from scutellum along suture to slightly beyond midline 
(Fig. 3). Elytra with distinct, fine and dense punctation. Diameter of punctures only slightly smaller than eye facet. Distances between punctures much smaller than puncture diameter, interspaces smooth, slightly shining.

Abdomen delicately shagreened.

Aedeagus of characteristic structure (Figs 11-12).

Female. Sexual dimorphism absent, female morphologically similar to male. Spermatheca of characteristic structure (Fig. 13).

COMPARATIVE REMARKS. The new species belongs to the "taprobanae" species group. In this group, the new species is very similar in size, colouration and punctation to a closely related species, Carpelimus (Trogophloeus) taprobanae (Walker, 1859), from which it can be clearly distinguished only by the structure of the aedeagus [Gildenkov, 2015b, p. 385, figs. 19: 10-11]. It differs from Carpelimus (Trogophloeus) vagans (Cameron, 1930) by its larger size, longer antennae and can be clearly distinguished by the structure of parameres and the morphology of sclerites in the central part of the sac of aedeagus [Gildenkov, 2015b, p. 396, figs. 19: 13].

\section{DISTRIBUTION. Nepal.}

ETYMOLOGY. From Latin gemini (twins) referring to a significant similarity to $C$. taprobanae.
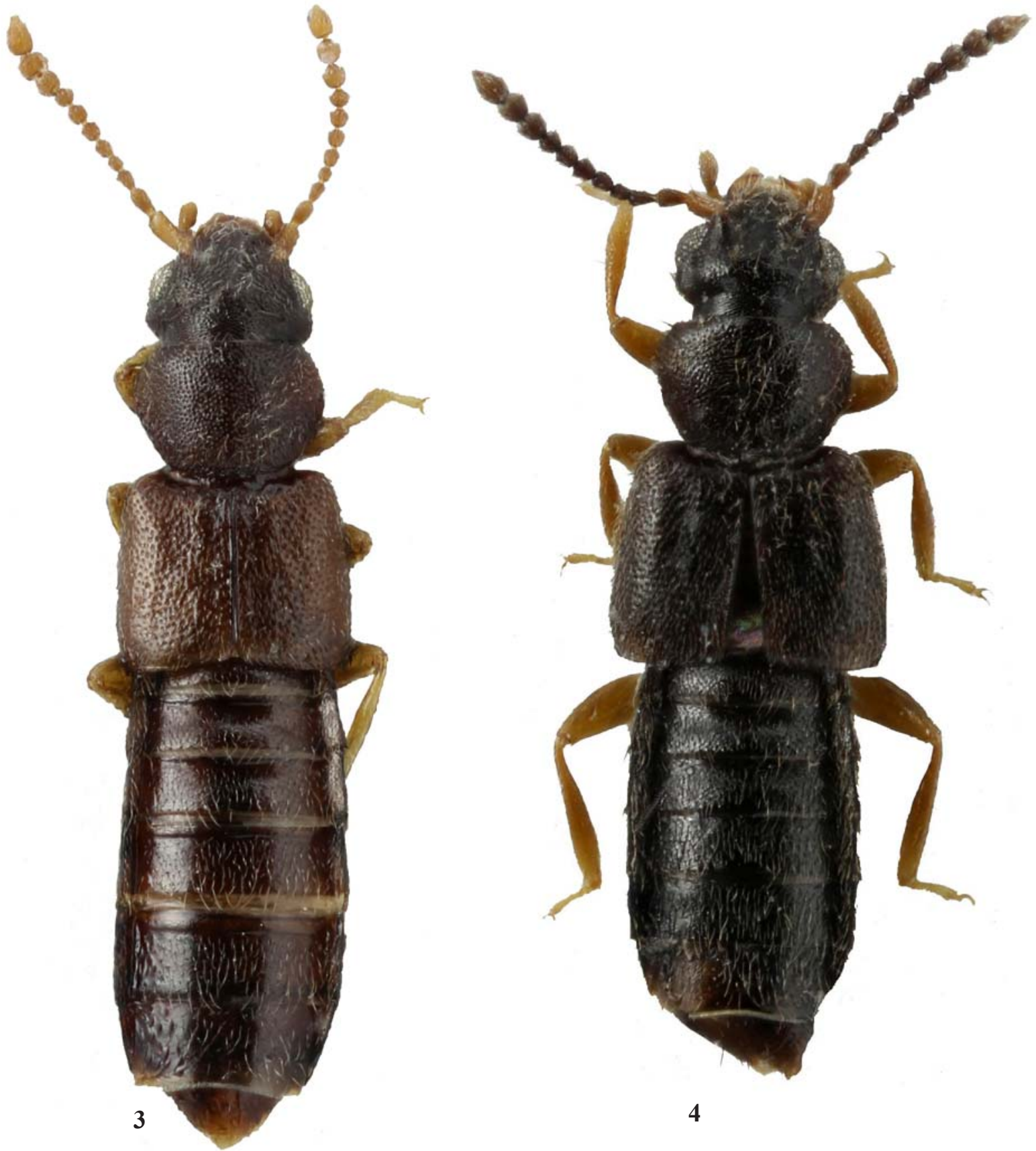

Figs 3-4. Carpelimus spp., males, dorsal view: 3 - Carpelimus (Trogophloeus) geminus, sp.n. (holotype); 4 - Carpelimus (Trogophloeus) guillaumi, sp.n. (paratype, Hong Kong).

Рис. 3-4. Carpelimus spp., самцы, сверху: 3 - Carpelimus (Trogophloeus) geminus, sp.n. (голотип); 4 - Carpelimus (Trogophloeus) guillaumi, sp.n. (паратип, Гонконг). 
Carpelimus (Trogophloeus) guillaumei Gildenkov, sp.n.

Figs. 4, 14-16.

MATERIAL. Holotype, o' "HONG KONG Fung Yuen 6.VI.1997 leg. G.T. Reels" "Flight interception trap" "Rougemont collection" "Holotypus Carpelimus guillaumei | det. M. Gildenkov, 2016" (cGR). Paratypes: 3 ex. "HONG KONG, Tai Po III.1996 | G. de Rougemont" "Leaf litter" "Paratypus Carpelimus guillaumei | det. M. Gildenkov, 2016" (cGR); $20^{\prime} \mathrm{O}^{\prime}, 2$ 2 9 " "HONG KONG, Tai Po III.1996 | G. de Rougemont" "Flight interception trap" "Paratypus Carpelimus guillaumei | det. M. Gildenkov, 2016" (cGR; 10", 1 우 cMG); $20^{7} 0^{7}, 2$, 2+, 5 ex. "HONG KONG Fung Yuen 6.VI.1997 leg.
G.T. Reels" "Flight interception trap" "Rougemont collection" "Paratypus Carpelimus guillaumei | det. M. Gildenkov, 2016" (cGR; $\left.10^{7}-\mathrm{cMG}\right) ; 1$ ex. "Hong Kong Mui tsz Lam 1.X.96 | G.T. Reels" "Flight interception trap" "Rougemont collection" "Paratypus Carpelimus guillaumei | det. M. Gildenkov, 2016" (cGR); 1 ex. "Hong Kong K.A.B.C. VI.92 G. Ades" "Malaise trap" "Rougemont collection" "Paratypus Carpelimus guillaumei det. M. Gildenkov, 2016" (cGR); 4우, 1 ex. "CHINA: B.M.1980-491 P.M. Hammond" "GUANGDONG: Guangzhou Baiyunshan 27.IX.80" "Paratypus Carpelimus guillaumei | det. M. Gildenkov, 2016" (BNHM; 1 우 cMG); $10^{7}$ "CHINA: Yunnan, Lincang Pref. Mekong valley, small creek cleft, $8 \mathrm{~km}$ SSE Lincang, $854 \mathrm{~m}, 23^{\circ} 33^{\prime} 13.2^{\prime \prime} \mathrm{N}, 100^{\circ} 05^{\prime} 56.8^{\prime \prime} \mathrm{E}$, wet litter \& flood debris under waterfall, 11.IX.2009, leg. M. Schülke
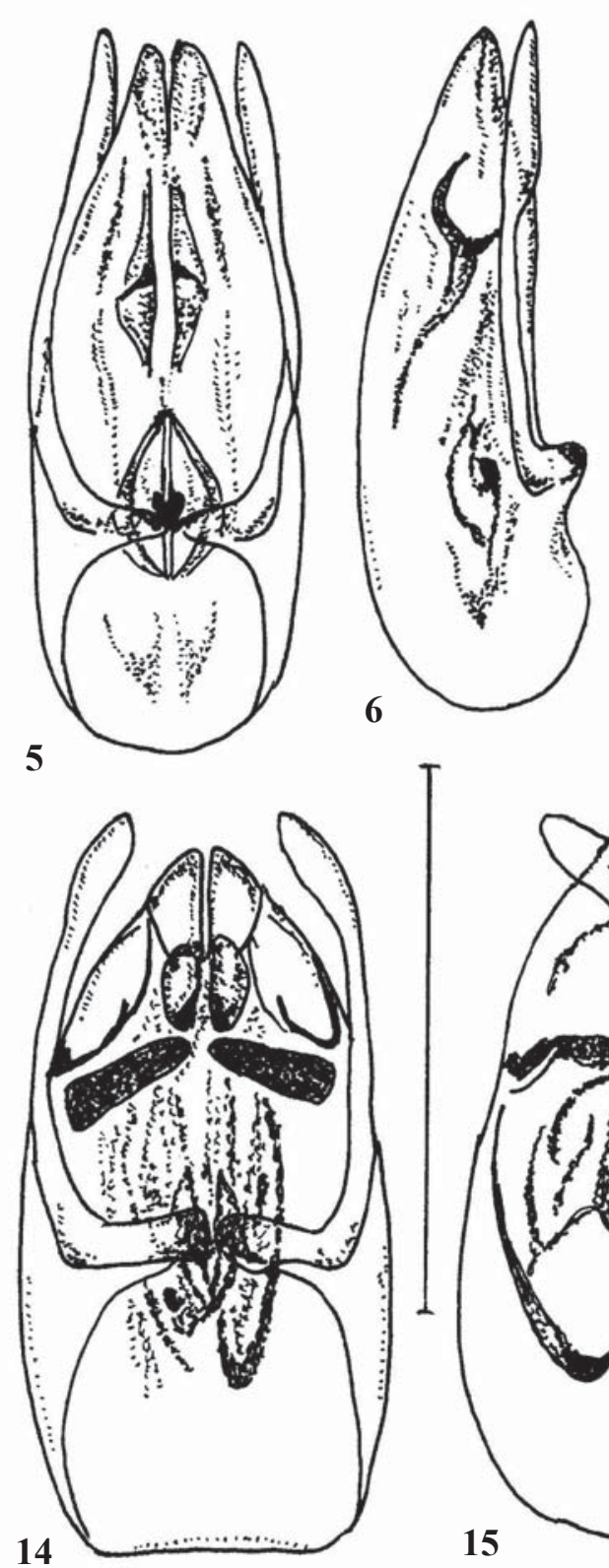

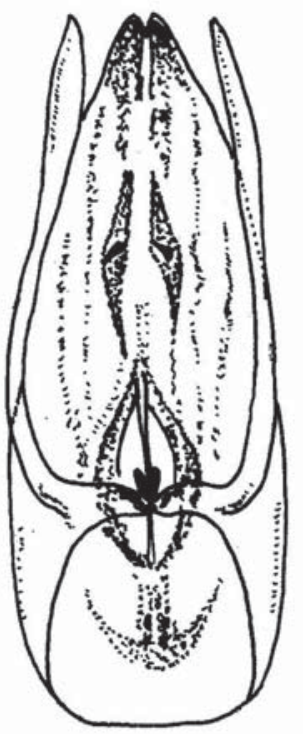

11
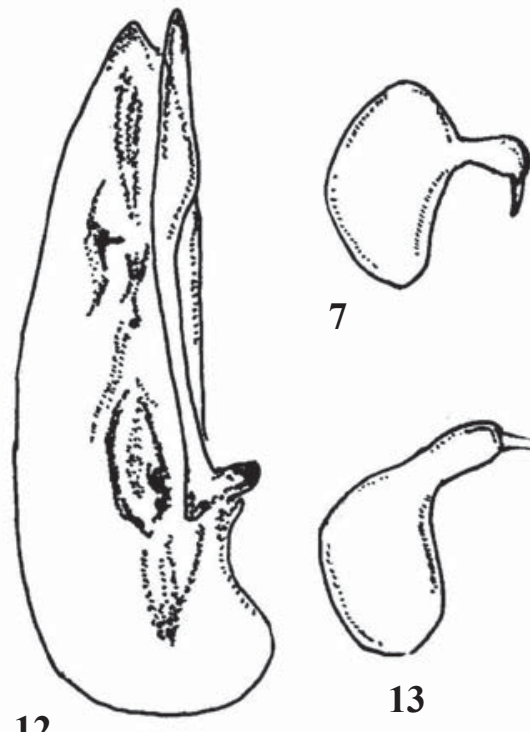

7

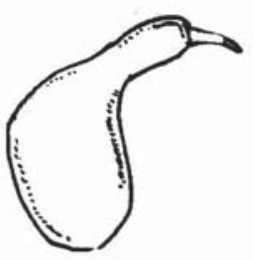

13

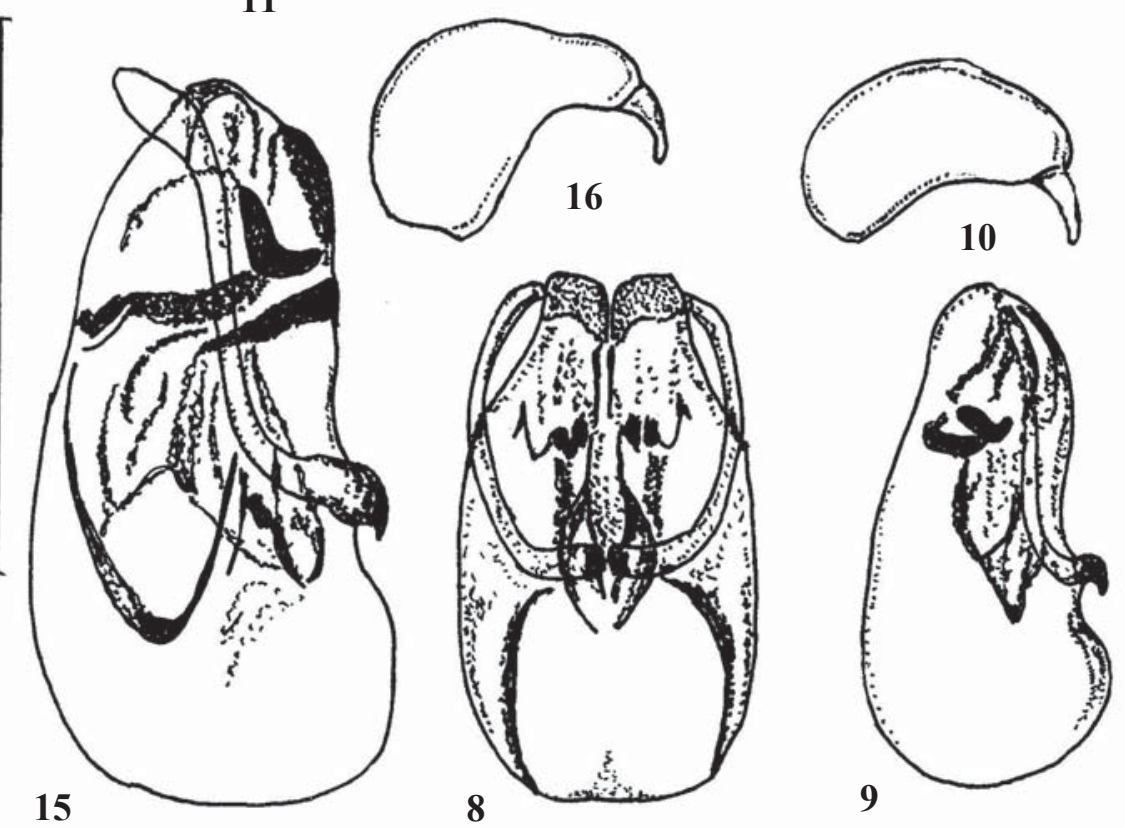

Figs 5-16. Genitalia of Carpelimus: 5-7 - C. asperus, sp.n.; 8-10-C. fuligus, sp.n.; 11-13-C. geminus, sp.n.; 14-16-C. guillaumi, sp.n.; 5, 8, 11, 14 - aedeagus, ventral view (holotypes); 6, 9, 12, 15 - aedeagus lateral view (holotypes); 7, 10, 13, 16 spermatheca (paratypes). Scale bar: $0.25 \mathrm{~mm}$.

Рис. 5-16. Гениталии Carpelimus: 5-7 - C. asperus, sp.n.; 8-10-C. fuligus, sp.n.; 11-13 - C. geminus, sp.n.; 14-16 - C. guillaumi, sp.n.; 5, 8, 11, 14 - эдеагус, снизу (голотип); 6, 9, 12, 15 — эдеагус, сбоку (голотип); 7, 10, 13, 16 — сперматека (паратип). Масштаб: $0.25 \mathrm{~mm}$. 
[CH09-44a]" "Paratypus Carpelimus guillaumei | det. M. Gildenkov, 2016" (cMSch); $10^{7}$ "W - THAILAND 1990 Tham Tharn Lot NP N Kanchanaburi (2), leg. Jäch 27.11." "Paratypus Carpelimus guillaumei | det. M. Gildenkov, 2016" (NHMW).

DESCRIPTION (holotype). Length $2.0 \mathrm{~mm}$. Colouration dark brown, legs and first 2 antennal segments yellowish brown. Integument slightly shining, body with short lightcoloured hairs.

Head transverse, with wide base, ratio of head length (from neck mid-length to anterior margin of clypeus) to its maximum width about 20:26. Neck constriction prominent. Eyes rather large, slightly convex. Temples well-developed, round, eye diameter in dorsal view slightly longer than temple length. Head widest across eyes (Fig. 4). Head surface with rather distinct, fine and dense punctation. Puncture diameter on vertex about twice as small as eye facet. Punctures on frons slightly smaller and more densely set. Distances between punctures slightly smaller than their diameter, interspaces smooth, slightly shining. Antennae rather short, antennal segments $1-6$ elongate; segments 7 and 8 about as wide as long; segments 9-10 slightly transverse; segment 11 elongate, conical. Last 3 segments more massive than others and form loose club (Fig. 4).

Pronotum widest about 2/3 its length from base, then narrowed. Lateral margin with small notch near base (Fig. 4). Ratio of pronotum length to its maximum width about 21:29. Surface of pronotum with rather distinct, fine and dense punctation, distances between punctures slightly smaller than their diameter, interspaces smooth, slightly shining. Punctation similar to that on vertex. Pronotal disc with 2 pairs of prominent, symmetrical depressions: 1 pair of narrowly crescent-shaped depressions on base and 1 pair of longitudinal, oval depressions in central part (Fig. 4).

Ratio of length of elytra to their combined width about $33: 40$. Elytra with shallow longitudinal depressions extending from scutellum along suture to slightly beyond midline (Fig. 4). Surface of elytra with rather distinct, fine and dense punctation. Diameter of punctures about 1.5 times as small as eye facet, punctures slightly larger than those on pronotum and head. Distances between punctures slightly smaller than their diameter, interspaces smooth, slightly shining.

Abdomen delicately shagreened.

Aedeagus of characteristic structure (Figs 14, 15).

Female. Sexual dimorphism absent, female morphologically similar to male. Spermatheca of characteristic structure (Fig. 16).

COMPARATIVE REMARKS. The new species is similar to Carpelimus (Trogophloeus) torrentum (Cameron, 1930) in colouration, size, punctation patterns and head structure. It differs by slightly more developed eyes, more lightly-coloured legs and an entirely different structure of the aedeagus [Gildenkov, 2015b, p. 396, figs. 30: 8].

DISTRIBUTION. South China, West Thailand.

ETYMOLOGY. Named after Guillaume de Rougemont (Oxford, UK), a well-known beetle collector and expert on Staphylinidae, who kindly provided the material for the study.

\section{Carpelimus (Bucephalinus) rubrus Gildenkov, sp.n.} Figs. 17-20.

MATERIAL. Holotype, $\sigma^{\top}$ "NE INDIA, ASSAM, Bhalukpong $27^{\circ} 02^{\prime} \mathrm{N} 92^{\circ} 35^{\prime} \mathrm{E}, 150 \mathrm{~m}$, L. Dembick leg., 26.v.-3.vi.2006 BMNH 2006-48" (BNHM). Paratypes: 4우 "NE INDIA, ASSAM, Bhalukpong $27^{\circ} 02^{\prime} \mathrm{N} 92^{\circ} 35^{\prime} \mathrm{E}, 150 \mathrm{~m}$, L. Dembick leg., 26.v.-3.vi.2006 BMNH 2006-48” (BNHM; 1 - $-\mathrm{cMG}$ ); $20^{7} 0^{\prime \prime}, 2$ 우 “NE INDIA,

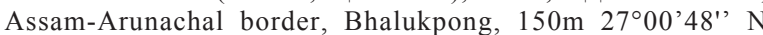

92³9’08' E, L. Dembick leg. 1.-8.v.2012”' (ZFMK; 10' - cMG); 1 우 "NEPAL, P: Narayani, D: Chitwan, Sauraha, Hotel Riversid, 190

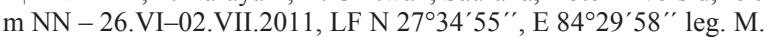
Hartmann, $0^{7} 54$ " (NKME).

DESCRIPTION (holotype). Length $2.3 \mathrm{~mm}$. Colouration brown. Head, abdomen and antennae dark brown, protonum and elytra reddish brown; legs and antennal bases yellowish brown. Integument slightly shining, body with short light hairs.

Head transverse, with wide base, ratio of head length (from neck mid-length to anterior margin of clypeus) to its maximum width about 21:28. Neck constriction prominent. Eyes rather large, convex. Temples rather well-developed, round, eye diameter in dorsal view about 1.5 times as long as temple length. Head widest across eyes (Fig. 17). Head surface with rather distinct and dense punctation. Many punctures on vertex umbilicate, their diameter slightly larger than eye facet. Punctures on frons simple, much smaller than those on vertex, their diameter more than twice as small as eye facet. Distances between punctures slightly smaller than their diameter, interspaces smooth, slightly shining. Antennae long, antennal segments 1-9 elongate; segment 10 about as wide as long; segment 11 elongate, conical. Last 3 segments more massive than others and form loose club (Fig. 17).

Pronotum widest about $2 / 3$ its length from base, then narrowed. Lateral margin with small notch near base (Fig. 17). Ratio of pronotum length to its maximum width about 24:31. Surface of pronotum with rather distinct and dense punctation. Many punctures umbilicate, their diameter on base of pronotum and along its lateral margin much larger than eye facet; punctation not uniform, central portion of pronotal disc with much smaller punctures. Distances between punctures much smaller than their diameter, interspaces smooth, slightly shining. Base of pronotal disc with prominent, symmetrical, narrowly crescent-shaped depressions, almost merging at midline. Central part of disc with rather deep, oval depressions merging across midline to single butterfly-shaped depression (Fig. 17).

Ratio of length of elytra to their combined width about 38:43. Scutellum with shallow round depressions (Fig. 17). Surface of elytra with rather distinct, fine and dense punctation. Diameter of punctures only slightly smaller than eye facet. Distances between punctures slightly smaller than their diameter, interspaces smooth, slightly shining.

Abdomen delicately shagreened.

Aedeagus of characteristic structure (Figs 18, 19).

Female. Sexual dimorphism absent, female morphologically similar to male. Spermatheca of characteristic structure (Fig. 20).

COMPARATIVE REMARKS. The new species is similar in the structure of the aedeagus and especially in the morphology of parameres [Gildenkov, 2015b, p. 378, figs. 12: 17] to Carpelimus (Bucephalinus) terribilus Gildenkov, 2014 from the Philippine Islands [Gildenkov, 2014c]. It differs by its distribution range, smaller size and a lighter colouration and can be clearly distinguished by the structure of the aedeagus.

DISTRIBUTION. North India, Nepal.

ETYMOLOGY. From Latin rubro (red) referring to a distinct reddish tinge in the color of the elytra.

ACKNOWLEDGEMENTS. The author wishes to thank all colleagues for making material available for the study: Roger Booth (BNHM); Guillaume de Rougemont (Oxford); Michael Schülke (Berlin); Alfred Newton, Margaret Thayer 


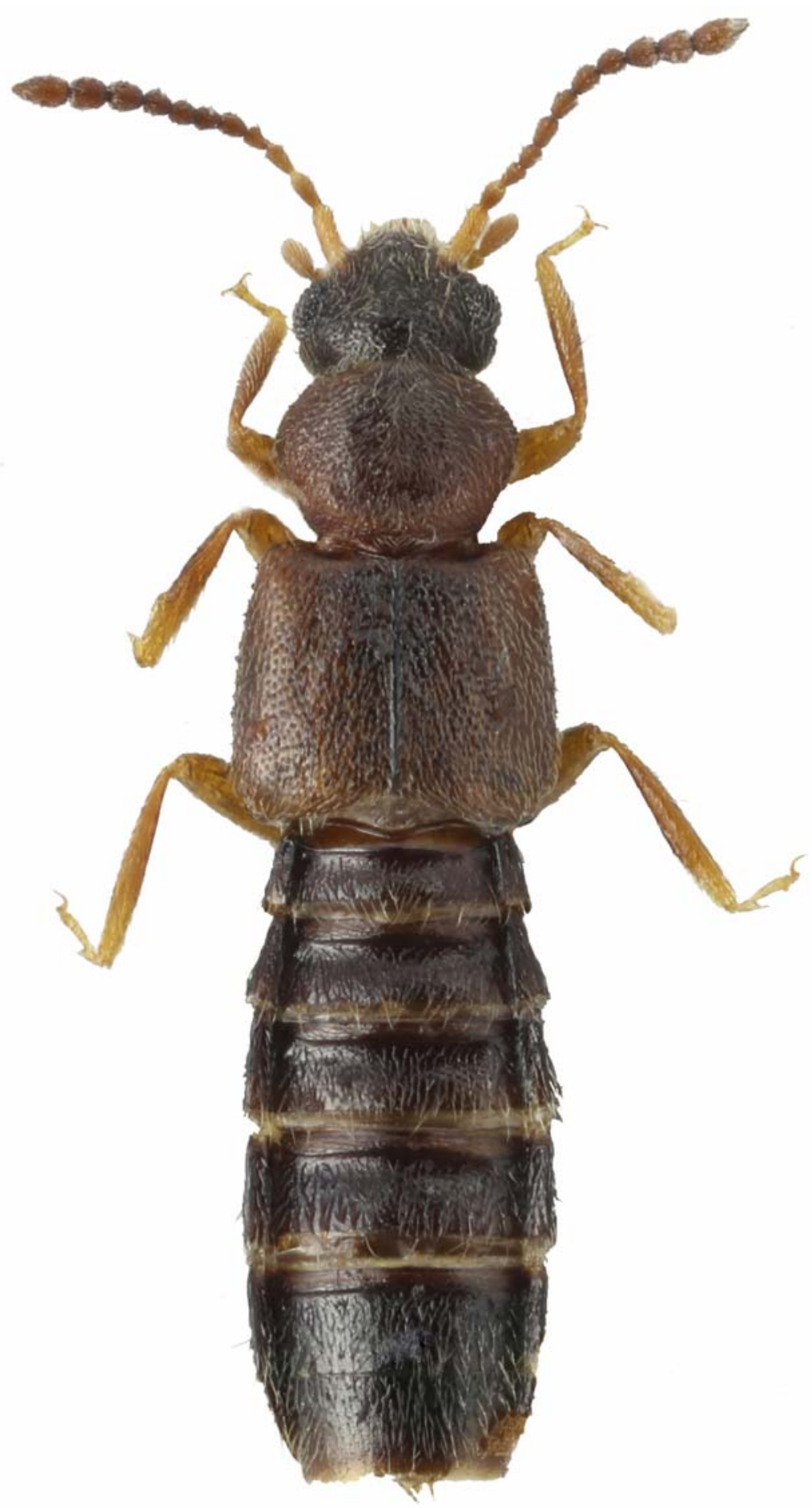

17
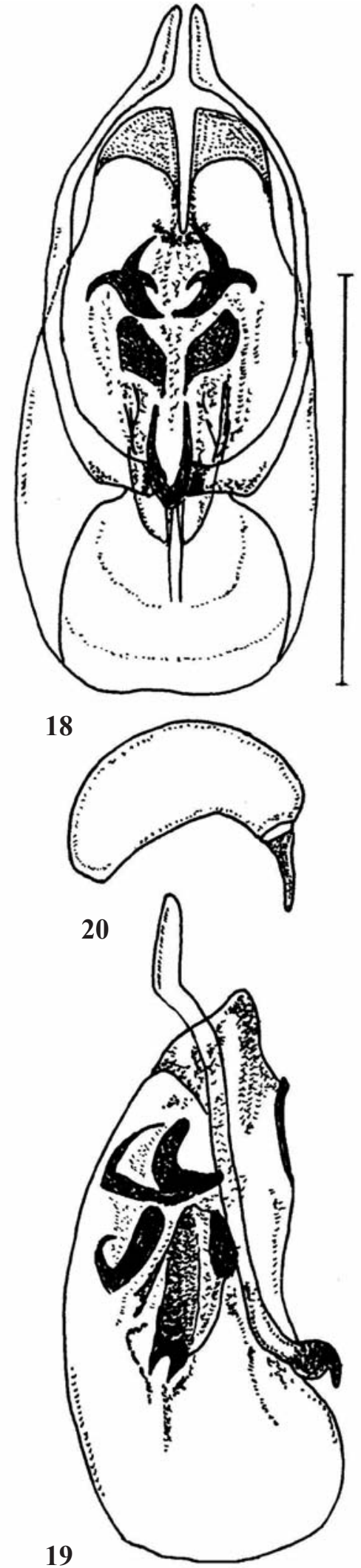

Figs 17-20. Carpelimus (Trogophloeus) rubrus, sp.n.: 17 - habitus, dorsal view; 18 - aedeagus, ventral view; 19 - aedeagus, lateral view; 20 - spermatheca; $17-19$ - holotype, male; 20 - paratype, female. Scale bar: $0.25 \mathrm{~mm}$.

Pис. 17-20. Carpelimus (Trogophloeus) rubrus, sp.n.: 17 - габитус, сверху; 18 - эдеагус, снизу; 19 - эдеагус, сбоку; 20 сперматека; 17-19 - голотип, самец; 20 - паратип, самка. Scale bar: $0.25 \mathrm{~mm}$. 
and James Boone (FMNH); Harald Schillhammer (NHMW); Matthias Hartmann (NKME); Dirk Ahrens (ZFMK). I also thank Kirill Makarov for taking the photographs (Moscow Pedagogical State University, Russia)

\section{References}

Gildenkov M.Yu. 2001a. [The fauna of Carpelimus of the Palaearctic (Coleoptera, Staphylinidae). Problems of species and speciation. Part 1. The history of research. Morpho-ecological features. System of the genus. Description of species]. Smolensk: SGPU. 304 pp. [In Russian]

Gildenkov M.Yu. 2001b. [The fauna of Carpelimus of the Palaearctic (Coleoptera, Staphylinidae). Problems of species and speciation. Part 2. Keys to species. The phylogenetic relations in genus. Problems of species and speciation]. Smolensk: SGPU. 176 pp. [In Russian]

Gildenkov, M.Yu. 2002. [System of the genus Carpelimus (Coleoptera, Staphylinidae) within the Palearctic. 1. General part and description of new taxa] // Zoologicheskii Zhurnal. Vol.81. No.12. P.1461-1475 [in Russian, with English summary].

Gildenkov, M.Yu. 2003a. [System of the genus Carpelimus (Coleoptera, Staphylinidae) within the Palearctic. 2. Keys for the determination of subgenera and subgenera species Carpelimus, Paratrogophloeus, Myopinus, Bucephalinus] // Zoologicheskii Zhurnal. Vol.82. No.1. P.22-34 [in Russian, with English summary].

Gildenkov, M.Yu. 2003b. [System of the genus Carpelimus (Coleoptera, Staphylinidae) within the Palearctic. 3. for the determination of subgenera species Trogophloeus and Troginus] // Zoologicheskii Zhurnal. Vol.82. No.3. P. 366-381 [in Russian, with English summary].

Gildenkov M.Yu. 2007a. [A review of the subgenus Carpelimus s.str. (Coleoptera, Staphylinidae) from tropical Africa] // Zoologicheskii Zhurnal. Vol.86. No.9. P.1073-1085 [in Russian, with English summary].

Gildenkov M.Yu. 2007b. [A review of the subgenus Troginus from genus Carpelimus (Coleoptera, Staphylinidae) from tropical Africa] // Zoologicheskii Zhurnal. Vol.86. No.11. P. 1315-1327 [in Russian, with English summary].

Gildenkov M.Yu. 2011a. [New species of Thinodromus Kraatz, 1857 and Carpelimus Leach, 1819 (Coleoptera, Staphylinidae, Oxytelinae) from the Palaearctic] // Izvestiya Smolenskogo Gosudarstvennogo Universiteta. No.2(14). P. 34-46 [in Russian, with English summary].

Gildenkov M.Yu. 2011b. [New species of Carpelimus Leach, 1819 from the Palaearctic and an addendum to the faunistic review of the subgenus Carpelimus (s. str.) for tropical Africa (Coleoptera, Staphylinidae, Oxytelinae)] // Izvestiya Smolenskogo Gosudarstvennogo Universiteta. No.4(16). P. 64-72 [in Russian, with English summary]

Gildenkov M.Yu. 2012. [A preliminary review of the subgenus Bucephalinus Koch, 1934 from the genus Carpelimus Leach, 1819 for tropical Africa (Coleoptera, Staphylinidae, Oxytelinae)] // Izvestiya Smolenskogo Gosudarstvennogo Universiteta. No.3(19). P. 245-256 [in Russian, with English summary].

Gildenkov M.Yu. 2013a (2012). [New species of the subgenus Trogophloeus Mannerheim, 1930 from the genus Carpelimus Leach,
1819 for tropical Africa (Coleoptera, Staphylinidae, Oxytelinae)] // Izvestiya Smolenskogo Gosudarstvennogo Universiteta. No.4(20). P. 266-294 [in Russian, with English summary].

Gildenkov M.Yu. 2013b. [A taxonomic review of the subgenus Trogophloeus Mannerheim, 1930 from the genus Carpelimus Leach, 1819 for tropical Africa (Coleoptera, Staphylinidae, Oxytelinae)] // Izvestiya Smolenskogo Gosudarstvennogo Universiteta. No.1(21). P. 242-251 [in Russian, with English summary].

Gildenkov M. Yu. 2013c. Designations of the lectotypes for the oriental species of the genus Carpelimus Leach, 1819 (Coleoptera: Staphylinidae) // Zootaxa. Vol.3717. No.1. P.53-64.

Gildenkov M.Yu. 2013d. [New species of the genus Carpelimus Leach, 1819 from the Palaearctic and Oriental Region (Coleoptera, Staphylinidae, Oxytelinae)] // Izvestiya Smolenskogo Gosudarstvennogo Universiteta. No.2(22). P. 167-187 [in Russian, with English summary]

Gildenkov M.Yu. 2013e. [Seven new species of the genus Carpelimus Leach, 1819 from the Oriental Region (Coleoptera, Staphylinidae, Oxytelinae)]// Izvestiya Smolenskogo Gosudarstvennogo Universiteta. No.3(23). P.221-236 [in Russian, with English summary].

Gildenkov M.Yu. 2014a (2013). [New species of the genus Carpelimus Leach, 1819 from the «silvestris» and «taprobanae» species groups (Coleoptera, Staphylinidae, Oxytelinae)] // Izvestiya Smolenskogo Gosudarstvennogo Universiteta. No.4(24). P. 292-305 [in Russian, with English summary].

Gildenkov M.Yu. 2014b. [Five new species of the genus Carpelimus Leach, 1819 from the Oriental Region and Palaearctic (Coleoptera, Staphylinidae, Oxytelinae)] // Izvestiya Smolenskogo Gosudarstvennogo Universiteta. No.2(26). P. 232-244 [in Russian, with English summary].

Gildenkov M.Yu. 2014c. [New species of the genus Carpelimus Leach, 1819 from the islands of Borneo, Philippines and Sulawesi (Coleoptera: Staphylinidae: Oxytelinae)] // Izvestiya Smolenskogo Gosudarstvennogo Universiteta. No.3(27). P. 183195 [in Russian, with English summary].

Gildenkov M.Yu. 2014d. On The taxonomy and distribution of the genus Carpelimus Leach, 1819 (Coleoptera: Staphylinidae: Oxytelinae) of Nepal// Baltic Journal of Coleopterology. Vol.14. No.1. P.21-31.

Gildenkov M.Yu. 2015a. New records of the genus Carpelimus Leach, 1819 (Coleoptera: Staphylinidae: Oxytelinae) from Taiwan // Acta Biologica Universitatis Daugavpiliensis. Vol.15. No.2. P.395-405.

Gildenkov M.Yu. 2015b. [Fauna of Carpelimus of the Old World (Coleoptera: Staphylinidae)]. Smolensk: SmolSU. 414 pp. [In Russian, with English summary]

Gildenkov M.Yu. 2016a. To the validity of Carpelimus rivus Gildenkov, 2011 (Coleoptera: Staphylinidae: Oxytelinae) // Acta Biologica Universitatis Daugavpiliensis. Vol.16. No.1. P.119121.

Gildenkov M.Yu. 2016b. New records of the species of Carpelimus Leach, 1819 (Coleoptera: Staphylinidae, Oxytelinae) from China // Far Eastern Entomologist. No.320. P.27-32.

Gildenkov M.Yu. 2017. New species of the genus Carpelimus Leach, 1819 from Central China (Coleoptera: Staphylinidae: Oxytelinae) // Russian Entomological Journal. Vol.26. No.2. P.103-104. 